\title{
Development of Calculus Teaching Material: Context of Universitas Timor, Indonesia
}

\author{
Yohanis Ndapa Deda, Hermina Disnawati \\ Universitas Timor, Jl. Eltari, km 09, Sasi, Kefamenanu, Indonesia \\ Email: yndapadeda@unimor.ac.id
}

\begin{abstract}
The current research development aims at producing a valid, practical, and useful deferential calculus teaching material. The teaching material referred to this study is a student worksheet with a constructivism approach. It applied development research method. It was conducted in two stages, namely preliminary analysis and formative evaluation stage. The results of the experts' validation stated that the teaching material developed has reached the correct category. The results of one-on-one trials class indicate that the developed the material can be accepted and be used. Furthermore, field trial results, which was conducted to see the effectiveness aspect, have met the criteria. In other words, the current research has produced a valid, practical, and useful derivative calculus teaching material that focuses on teaching material and its supporting components, including syllabus, and lesson plans.
\end{abstract}

Keywords: development, teaching materials, derivative calculus, constructivism

How to Cite: Deda, Y.N., \& Disnawati, H. (2020). Development of Calculus Teaching Material: Context of Universitas Timor, Indonesia. International Journal on Emerging Mathematics Education, 1(1), 105-114. http://dx.doi.org/10.12928/ijeme.v4i2.15976

\section{INTRODUCTION}

Calculus is a necessary and compulsory course, programmed by both mathematics education students and other exact fields such as information technology, chemistry, and biology. The role of Calculus is significant as a basis for students' basic knowledge. It is needed to understand mathematical concepts. Moreover, it is a prerequisite for programming courses on Real Variable Analysis, Complex Analysis, Advanced Calculus, Numerical Analysis, and Algebraic Structure in universities. For students of mathematics education study program, as teacher candidates, the understanding of calculus material, such as the concept of limits, derivatives, and integrals, is necessary because it becomes the subject of teaching mathematics at the secondary school level.

The facts show that calculus is still a frightening spectre for most students. Based on the data from the Universitas Timor (Unimor) mathematics education study program, it is found that in the last three years, many students did not pass Calculus I. In 2016 , there were 20 students, or $24 \%$ of 83 participants did not pass calculus I. In 2017 , there were 36 students or $24 \%$ of 150 participants failed calculus I, while in 2018, there were 50 students or $42 \%$ of 120 participants did not pass calculus I. As a result, many students could not join the program of Calculus II, Real Analysis, Differential Equations, and other courses because, as has been stated, Calculus I is the main prerequisite.

Many factors can influence the underperformance of students in Calculus courses. Ramdani (2012) states that one of the most influential factors is the availability of teaching materials. The fact shows that up to now, in Unimor 
Mathematics Education Study Program, there is no ready-made teaching material. The lecturers only use the main reference books written by Dale and Purcell \& Rigdon. It makes students difficult to directly understand the material in the book because there are no other supporting teaching materials.

Figure 1 shows the tendency of GPA, in this case, GPA of Mathematics Education Study Program Students, in the last five years. It shows a downward trend phenomenon. It happened in the second year, namely Students from 2013 to 2016. While the first year (red colour chart), students experienced a trend decreased, namely from 2014 to 2017.

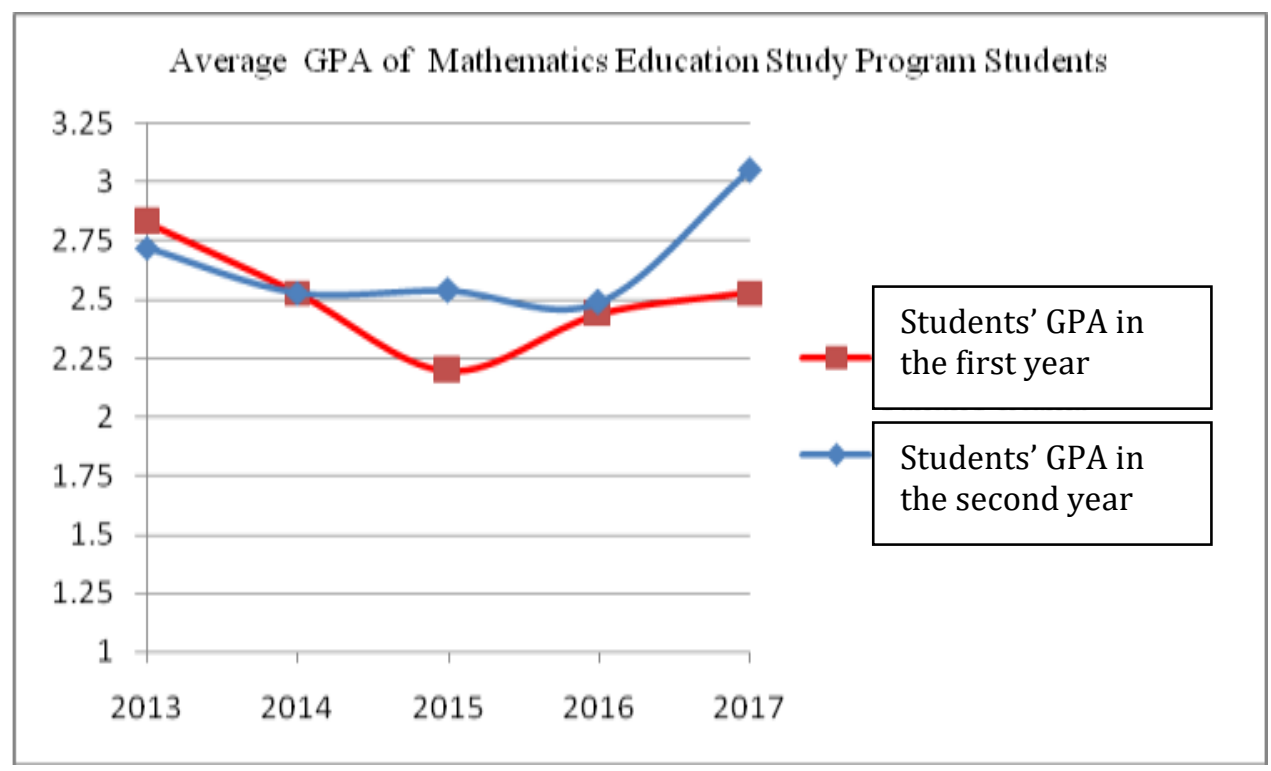

Figure 1. Average GPA in Mathematics Education Study Program Students

Based on the graph above, the failure rate is high. It can be seen from the average failure rate of students in the Calculus I course of the last three years. Each year, there were 35 students who did not pass the course. Students' achievement was also low. It is seen in GPA average of semester II students of Academic Year $2015 / 2016,2016 / 2017$, and 2017/2018. The average GPA was 2.20, 2.44, and 2.53. It is believed that one of the reasons for the low graduation rate in calculus I, and the low GPA of students, is the lack of learning resources and the absence of suitable teaching materials. Undeniable, lecturers were rarely using Student Worksheets (S.W.) in the lecture process.

In other words, one of the factors that influence the above problems is related to the use of learning resources by lecturers that have not been optimal. In reality, based on data, lecturers only used textbooks/ primary references without using teaching materials such as modules, handouts, and S.W. that are specially designed and systematically arranged according to the context and background of the university.

Moreover, the availability of learning resources in Calculus I course, which are following the necessary abilities of mathematics, especially the ability of students in the Indonesian border region, is still low. The underlying mathematical abilities of prospective teacher students still lack because they still use immeasurable words, unclear learning objectives, and choose topics that are not relevant (Istihapsari et al., 2019). For this reason, constructivism-based teaching material needs to be developed.

IJEME, Vol. 4, No. 2, September 2020, 105-114. 
It is needed to create students'attractive for studying Calculus courses. Furthermore, it is believed that the developed material will be able to increase students' motivation as well as learning achievement.

The teaching materials can help students learning independently, that is by utilizing their prior knowledge to improve their abilities (Bakar et al., 2018). The use of differential Calculus teaching materials, based on the open-ended approach, has been shown to have improved learning quality. There are also differences in the increase of students' mathematical representation ability (Gordah \& Fadillah, 2014). The construction of teaching based on teaching materials can also help students thinking critically (Setyawan et al., 2020). The constructivism approach requires each student to actively participate, learn independently, develop their knowledge actively, while lecturers only act as facilitators and mediators in the lecture process. (Hamdunah et al., 2016). Therefore, the current research, to develop teaching materials, is viewed as an essential one.

\section{RESEARCH METHOD}

This research applied principles of development research method with formative research type. It was conducted in two stages, namely, preliminary analysis and formative evaluation stages (Tessmer, 1993). Furthermore, the current research was conducted in Universitas Timor- Indonesia (Unimor), especially in the Mathematics Education Study Program. It involved 40 students who were taking Calculus I program.

\section{Research Procedure}

\section{Preliminary Analysis Phase}

This stage is also called as the preparation stage. This stage is the initial step of development research. At this stage, the researcher determined the research subject in coordination with the head of the mathematics education study program. Besides, other preparations, such as arranging research schedules, were also conducted. At this stage, the researcher conducted various analyzes of the approaches used by lecturers, such as analyzing the content of course descriptions, learning approaches, teaching materials, and learning resources. Moreover, the students' ability and achievement were also be analyzed.

\section{Formative Evaluation Stage}

This formative evaluation phase consists of Self Evaluation, Expert Review, One to One, Small Group, and Field Test (Tessmer, 1993; Zulkardi, 2002; Deda \& Disnawati, 2019). These stages are presented in Figure 2. 


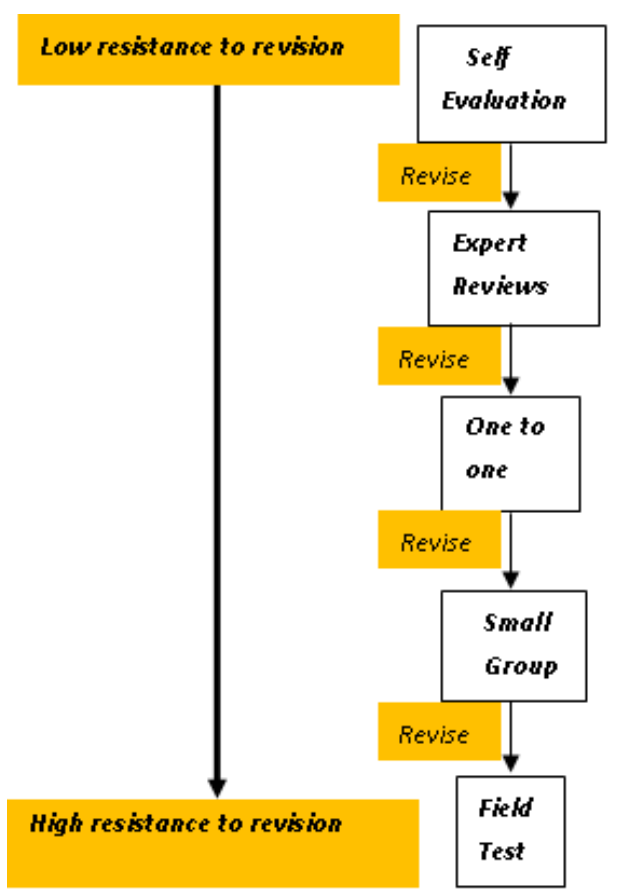

Figure 2. Research Procedure (Deda \& Disnawati, 2019)

\section{Data analysis technique}

\section{Document Analysis}

In the Self-evaluation stage, the document was analyzed so that the researcher knows whether the teaching material developed was following the students' abilities standards or not. The stage is essential in order to construct the teaching material produced in the prototype. Analysis of documents at one to one stage intended to analyze the practicality of the learning device on the second prototype obtained from the view of students. The results of this analysis were applied to revise the second prototype, which then produced the third prototype.

\section{Walk Through Analysis}

Analysis at this stage was conducted after gaining the results of Walk Through (at the expert review stage). Based on comments or suggestions from experts, qualitative learning tools could be produced. The analysis of this stage was carried out on the prototype and then obtained the second prototype.

\section{Test Analysis}

The data obtained from the test results were analyzed based on the ability of students that based on the scores obtained by students after the students have finished exercise given. Based on this analysis, the second prototype was constructed.

\section{Observation Analysis and Interviews Analysis}

Interview data that was conducted in the current stage were analyzed descriptively. It aimed at finding students' opinions regarding the teaching material developed. The results of the interviews were also analyzed. It was conducted to see how the questions on the prototypes could be solved correctly and adequately. Then, the observational data was conducted to find out the views of students.

IJEME, Vol. 4, No. 2, September 2020, 105-114. 


\section{RESULT AND DISCUSSION}

The final product development has been obtained through two stages of product development, namely the preliminary analysis stage and the formative evaluation stage (Tessmer, 1993). The first stage in this research, as stated previously, was the preparation phase, which aimed at analyzing the syllabus of Calculus 1 courses and the curriculum of the Mathematics Education program of Universitas Timor. The preliminary data of the current study was the student's GPA data.

The data was collected to determine the ability level (low, medium, and high level) of students who have involved in the second stage. The second stage was a formative evaluation, which consisted of self-evaluation, expert review, one to one trial, small group trial, and field trial.

\section{Self-Evaluation}

At this stage, the research team designed the Student Worksheet (S.W.) according to the syllabus and Lesson Plan of calculus I. After that, a personal evaluation was conducted.

\section{Expert Review}

Expert validation on the development of Calculus' S.W. involved three experts, namely material/content expert, design expert, and linguist.

\section{Expert Validation about the Content}

Figure 3 shows the validation of the content expert.

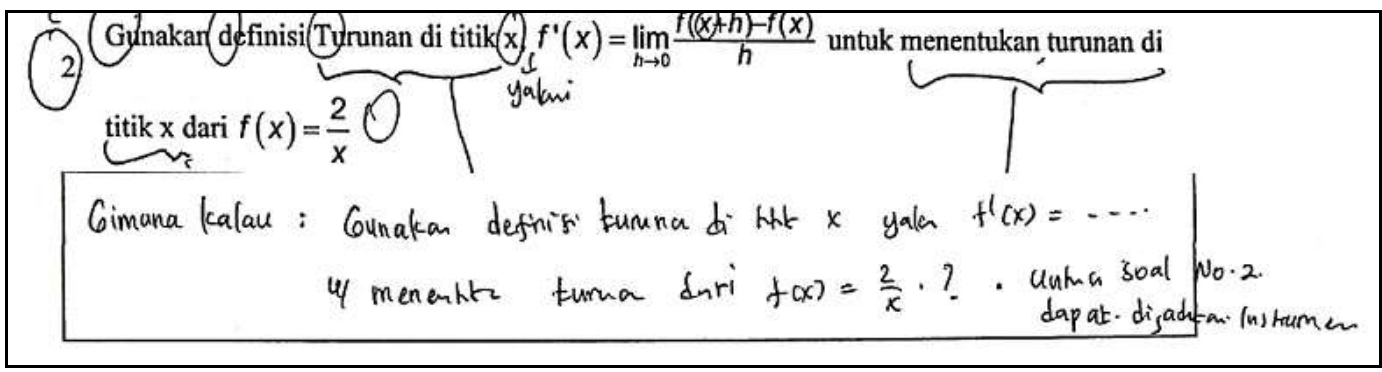

Figure 3. Expert comment on matter number 1

Content expert suggests that the material should use derivative content. Students, based on content expert views, will quickly understand the use of derivative content or definitions. Therefore, the formulation must be changed by using derivative definitions at the point $x$, namely $f^{\prime}(x)=\lim _{h \rightarrow 0} \frac{f(x+h)-f(x)}{h}$ to determine the derivative of $f(x)=\frac{2}{x}$ ! Such as Figure 4

2. Gunakan definisi turunan di titik $x$, yaitu $f^{\prime}(x)=\lim _{h \rightarrow 0} \frac{f(x+h)-f(x)}{h}$ untuk menentukan turunan dari $f(x)=\frac{2}{x}$ !

Jawaban:

Figure 4. Results of revision of material expert comments 
Moreover, the researcher designed seven questions on Calculus 1 S.W. However, the content expert did not agree with question number 7. It is not agreed related to approximations and differentials included in the enrichment material. (see in Figure 5)

\section{Dengan menggunakan diferensial, tentukan hampiran dari $\sqrt{35,9}$ \\ Penyelesaian:

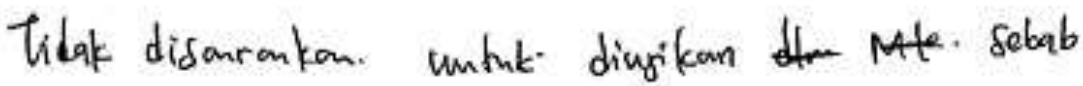 Matoris terkait hampiran den diferental, Idt sempont digartor (.Masule dalan pengayaar).}

Figure 5. Expert comments on matter number 7

Note:

Translation of Expert suggestion:

It is not suggested to be included since the material is different. It is not taught in Calculus 1.

Next, the constructed material is evaluated by a design expert. It is presented in Figure 6.

$$
\begin{aligned}
& \text { 1. Gunakan definisi Turunan di titik c, } f^{\prime}(c)=\lim _{h \rightarrow 0} \frac{f(c+h)-f(c)}{h} \text { untuk menghitung } f^{\prime}(1) \text { jika } \\
& f(x)=x^{2} \\
& \text { Penyelesaian: }
\end{aligned}
$$

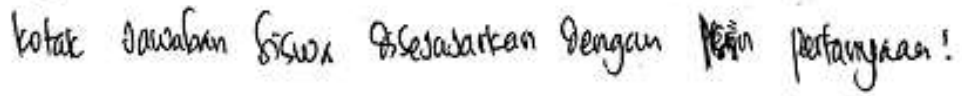

Figure 6. Example of expert design comments on item number 1

The expert of design gave input so that the appearance of the answer box question number 1 should be changed by swiping to the right to match the question-the revision result is presented in the following Figure 7.

$$
\begin{aligned}
& \text { 1. Gunakan definisi turunan di titik } \mathrm{c} \text {, yaitu } f^{\prime}(c)=\lim _{h \rightarrow 0} \frac{f(c+h)-f(c)}{h} \text { untuk menghitung } f^{\prime}(1) \\
& \text { jika } f(x)=x^{2} \text { ! } \\
& \text { Jawaban: }
\end{aligned}
$$

Figure 7. Results of revision of the design expert comments

IJEME, Vol. 4, No. 2, September 2020, 105-114. 
Furthermore, it is presented the validation of a linguist. The validation is shown in Figure 8.

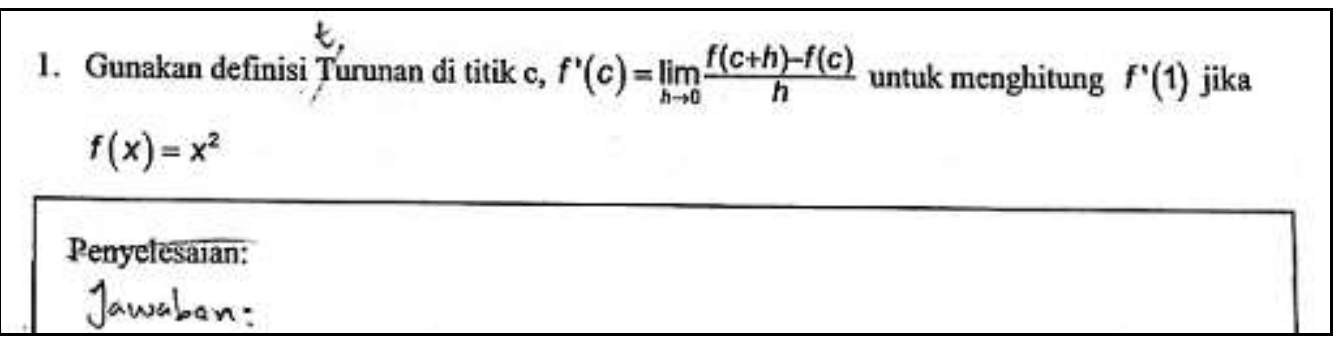

Figure 8. Comment of linguist

A linguist provides comments on how to write question number 1 on S.W. Calculus 1. It must be presented correctly, based on Bahasa Indonesia rules. The suggestions related to (1) the use of capital letters in the word Turunan 'Derivative'. It should be written turunan 'derivative' (without a capital letter). Next, the word Penyelesaian 'Settlement' should be replaced with the Jawaban 'Answer'.

\section{One-to-one trial phase}

This stage, as explained before, aimed at finding out whether the S.W. of Calculus 1 developed is suitable or not. The S.W. was tested on three students who represented low, medium and high ability students. The students' names were symbolized as NSL, AGF, and EPL.

The interview results obtained show that questions number 5 and 6 are too difficult because they have not been taught in Calculus 1 . However, numbers 1, 2, 3, and 4 are understood. They have no significant difficulties.

Since there are two questions in the developed S.W. that are eliminated, then the preparation time of 100 minutes becomes inefficient. Therefore, at this stage, it is also obtained input regarding the duration. They suggested that the duration of doing exercises should only take 50 minutes for four questions.

\section{The trial phase}

The limited trial phase (small group) aimed at getting views from students related to S.W. Calculus 1 material developed. At this stage, it involved six students, namely two low-capacity students, namely MLH and AN, two medium-capable students, namely HS and MGB and two high-ability students, namely MDF and AM. The results of this small class trial indicate that S.W. Calculus 1 derived material is acceptable and can be used well. The statement is based on the work of students who have been able to finish questions in the S.W. The interview results also showed that low, medium and high ability students did not experience significant difficulties in working on the questions in the S.W.

\section{Field trial phase}

Before conducting field trials on S.W. of Calculus 1, a pre-test, which aims at measuring the initial ability of students, was conducted. The results of pre-test are shown in Table 1 and 2. 
Table 1. Students' Pretest Results

\begin{tabular}{cccc}
\hline Students' Score & $\begin{array}{c}\text { Number of } \\
\text { Students }\end{array}$ & $\begin{array}{c}\text { Presentati } \\
\text { on }\end{array}$ & Category \\
\hline $80-100$ & 1 & $3 \%$ & Reached \\
$70-79$ & 7 & $21 \%$ & Reached \\
$60-69$ & 3 & $9 \%$ & Reached \\
$50-59$ & 13 & $30 \%$ & Unreached \\
$40-49$ & 9 & $27 \%$ & Unreached \\
\hline Total & 33 & $100 \%$ & \\
\hline
\end{tabular}

Table 2. Students' Posttest Results

\begin{tabular}{cccc}
\hline Students' Score & $\begin{array}{c}\text { Number of } \\
\text { Students }\end{array}$ & Presentation & Category \\
\hline $80-100$ & 6 & $18 \%$ & Reached \\
$70-79$ & 13 & $39 \%$ & Reached \\
$60-69$ & 11 & $33 \%$ & Reached \\
$50-59$ & 3 & $9 \%$ & Unreached \\
$40-49$ & 0 & $0 \%$ & Unreached \\
\hline Total & 33 & $100 \%$ & \\
\hline
\end{tabular}

The results of the pre-test in table 1 above show that from 33 students who took the pre-test, there is $57 \%$ of students have not reached the learning outcomes. However, after students used the developed S.W. in class, the learning outcomes test is different. As shown in table 2, 30 students of 33 students or $91 \%$ of students have achieved learning outcomes in Calculus 1. Furthermore, based on a questionnaire distributed, after students joined the developed S.W., students felt happy and motivated to join the lecture.

\section{CONCLUSION}

Based on the results and discussion that have been described above, it is concluded that the S.W. of Calculus I, using the constructivism approach, has met the valid, practical, and sufficient criteria for improving learning achievement in Calculus 1 Course. Therefore, the developed material is suggested to be applied in Calculus 1 class, especially in the context of East Indonesia (border area of Indonesia and Timor Leste).

\section{ACKNOWLEDGEMENTS}

The authors would like to thank LPPM Universitas Timor for the financial support for this research.

\section{REFERENCES}

Bakar, M.T., Waliyanti, I.K., \& Saidi, S. (2018). Modul Berbasis Reflektif Untuk Meningkatkan KemampuanMatematis Mahasiswa pada Perkuliahan Kalkulus I. JNPM (Jurnal Nasional Pendidikan Matematika), 2(2), 296-303.

Deda Y N. \& Disnawati, H. (2019). Pengembangan Lembar Kerja Mahasiswa (LKM) Etnomatematika Menggunakan Konteks Motif Kain Tenun Timor. Jurnal Karya Pendidikan Matematika (JKPM), 6(2):20-26.

IJEME, Vol. 4, No. 2, September 2020, 105-114. 
Gordah, E.K. \& Fadillah, S. (2014). The Effect Of Using Differential Calculus Textbook Based On Open-Ended Approach Towards Students'mathematical Representation Ability. Jurnal Pendidikan dan Kebudayaan, 20(3), 340-352.

Istihapsari, V., Istiandaru, A., \& Rohmah, S.N. (2019). Pre-Service Teachers' Skills in Analyzing the Mathematics Competency Based on Bloom Taxonomy. International Journal on Emerging Mathematics Education (IJEME), 3(2), 117-128.

Ramdani. 2012. Pengembangan instrumen dan bahan ajar untuk meningkatkan kemampuan komunikasi, penalaran, dan koneksi matematis dalam konsep integral. Jurnal UPI,13(1), 44-52.

Tessmer, M. (1993). Planning and Conducting Formative Evaluations. Philadelphia: Kogan Page.

Varberg, D., Purcell, E.J and Rigdon, S. E., (2007) Calculus Ninth Edition. New York: Pearson International Edition.

Zulkardi. (2002). Developing a Learning Environment on Realistic Mathematics Education for Indonesian student Teachers. Dissertation. Enschede: University of Twente. 
IJEME, Vol. 4, No. 2, September 2020, 105-114. 